USEPA. 1993. Methods for the determination of inorganic substances in environmental samples. EPA/600/R-93/100. Method 365.1. U.S. Gov. Print. Office, Washington, DC.

Valk, H., J.A. Metcalf, and P.J.A. Withers. 2000. Prospects for minimizing phosphorus excretion in ruminants by dietary manipulation. J. Environ. Qual. 29:28-36.
Wu, Z., L.D. Satter, and R. Sojo. 2000. Milk production, reproductive performance, and fecal excretion of phosphorus by dairy cows fed three amounts of phosphorus. J. Dairy Sci. 83:1028-1041.

Zemenchik, R.A., N.C. Wollenhaupt, K.A. Albrecht, and A.H. Bosworth. 1996. Runoff, erosion, and forage production from established alfalfa and smooth bromegrass. Agron. J. 88:461-466.

\title{
Bermudagrass Management in the Southern Piedmont USA. II. Soil Phosphorus
}

\author{
A. J. Franzluebbers, * J. A. Stuedemann, and S. R. Wilkinson
}

\begin{abstract}
Plant production can be limited by low levels of available $\mathbf{P}$ due to high P-fixation capacity in soils of the southeastern USA. On the other hand, there is increasing concern about excessive application of $\mathbf{P}$ to soil, especially when manure application is based upon $\mathbf{N}$ content. We evaluated changes in Mehlich-I extractable soil $\mathbf{P}$ during 5 yr of bermudagrass [Cynodon dactylon (L.) Pers.] management varying in fertilization [inorganic and broiler chicken (Gallus gallus) litter] and harvest strategy (unharvested, low and high cattle (Bos taurus) grazing pressure, and haying). Broiler litter supplied eight times more $P$ than inorganic fertilization to meet the $\mathbf{N}$ requirement. At a depth of 0 to $6 \mathrm{~cm}$, Mehlich-I extractable soil $P$ increased $0.8 \pm$ $1.6 \mathrm{mg} \mathrm{kg}^{-1} \mathrm{yr}^{-1}$ (4 $\pm 8 \%$ of total $P$ added) with inorganic-only fertilization, $2.4 \pm 3.0 \mathrm{mg} \mathrm{kg}^{-1} \mathrm{yr}^{-1}(9 \pm 11 \%$ of total $P$ added $)$ with clover (Trifolium incarnatum $L_{\text {.) }}$ cover crop plus inorganic fertilization, and $8.7 \pm 9.8 \mathrm{mg} \mathrm{kg}^{-1} \mathrm{yr}^{-1}(6 \pm 7 \%$ of total $\mathrm{P}$ added) with broiler litter. Haying kept Mehlich-I extractable soil $P$ constant with time due to removal of $P$ with harvest of biomass. At the end of $5 \mathrm{yr}$ of broiler litter application to grazed land, Mehlich-I extractable soil $P$ was 135, 50,22 , and $4 \mathrm{mg} \mathrm{kg}^{-1}$ higher than with inorganic fertilization at depths of 0 to 3,3 to 6,6 to 12 , and 12 to $20 \mathrm{~cm}$, respectively. Broiler litter fertilization was effective at increasing Mehlich-I extractable soil $P$ to an agronomically productive level (50 to $60 \mathrm{mg} \mathrm{kg}^{-1} 15 \mathrm{~cm}^{-1}$ ), but continued application could lead to excessive $P$ accumulation that could threaten water quality from surface runoff unless appreciable soil fixation or removal of forage biomass were to occur.
\end{abstract}

$\mathrm{L}$ ATERAL AND VERTICAL DISTRIBUTION of nutrients in pastures can either limit plant-animal productivity or pose environmental threats, depending upon quantities available and the type of management employed. In the southeastern USA, rainfall is abundant and soils are weathered, which make nutrient applications susceptible to both runoff and leaching losses. The eroded and weathered soils of the southeastern USA, in general, are low in available $\mathrm{P}$, with applied $\mathrm{P}$ quickly fixed into unavailable forms upon exposure to clay-sized minerals (Anderson et al., 1996). Crop responses to fertilizer application of $\mathrm{P}$ are generally large, but repeated applications are necessary because of the high anion adsorption capacity of these soils, particularly in the clayey subsoil,

USDA-ARS, J. Phil Campbell Sr. Natural Resource Conservation Center, 1420 Experiment Station Road, Watkinsville, GA 30677-2373. Received 19 Feb. 2001. *Corresponding author (afranz@arches.uga. edu).

Published in Soil Sci. Soc. Am. J. 66:291-298 (2002). which can become exposed at the soil surface from a long history of erosion (Bruce et al., 1990).

Poultry production in the Appalachian Piedmont is extensive (U.S. Dep. of Commerce, 1992). Manure mixed with bedding material (i.e., litter) at the end of the production cycle is cleared from confinement housing and applied to nearby land as a source of valuable nutrients for crop and pasture production. Depending upon management, however, repeated application of poultry litter to the same land could become a source of excessive nutrients that would threaten water quality (Sharpley et al., 1993; Kingery et al., 1994). Environmental regulations to protect water quality have and will continue to be developed, especially with the increased competition for water resources among agricultural-, urban-, wildlife-, and recreational-supporting sectors of our increasingly affluent society. Unfortunately, details on nutrient accumulation and distribution in soils managed for pasture production with differences in harvest strategy are limited. Such information is necessary for legislators to make rational decisions on land use and nutrient management based on scientific evidence.

Grazing of a forage crop compared with haying returns most of the manure directly to the land, which affects nutrient distribution in soil (Haynes and Williams, 1993; Follett and Wilkinson, 1995). Animal behavior patterns in pastures suggest that preferential deposition of feces and urine near shade and water sources would lead to a non-uniform distribution of nutrients (Mathews et al., 1996). Further, the impact of whether forage is mechanically harvested or not on total and extractable soil $\mathrm{P}$ deserves attention, based on the extent of land currently managed under the Conservation Reserve Program. Harvest management would be expected to alter the depth distribution of extractable soil $\mathrm{P}$, because of the presence of animal traffic, ruminant processing of forage (i.e., biological transformation of nutrients), or nutrient removal in hay.

We hypothesized that with equivalent amounts of total $\mathrm{N}$ applied, fertilization strategy (i.e., inorganic or organic with differences in associated $\mathrm{P}$ content) could affect the availability of $\mathrm{P}$ to forage and its form and depth distribution in soil. Our objective was to characterize the temporal and spatial distribution of Mehlich-I extractable soil $\mathrm{P}$ in response to differences in fertiliza-

Abbreviations: ICPS, inductively coupled plasma spectroscopy. 
Table 1. Characteristics and rates of fertilizer sources applied.

\begin{tabular}{|c|c|c|c|c|c|c|c|c|c|c|c|c|c|}
\hline \multirow[b]{2}{*}{ Variable } & \multicolumn{2}{|c|}{1994} & \multicolumn{2}{|c|}{1995} & \multicolumn{2}{|c|}{1996} & \multicolumn{2}{|c|}{1997} & \multicolumn{2}{|c|}{1998} & \multicolumn{3}{|c|}{ 5-yr mean } \\
\hline & May & July & May & July & May & July & May & July & May & July & $\mathrm{yr}^{-1}$ & $\mathbf{E q} \dagger$ & Eq \\
\hline & \multicolumn{10}{|c|}{$-\mathbf{g ~ m}^{-2}$} & $\mathrm{~g} \mathrm{~m}^{-2} \mathbf{y r}^{-1}$ & \multirow{2}{*}{\multicolumn{2}{|c|}{$\mathbf{m g ~ k g} \mathbf{~ g r}^{-1} \mathbf{y r}^{-1}$}} \\
\hline \multicolumn{12}{|c|}{$\underline{\text { Inorganic only }}$} & & \\
\hline $\mathbf{N}$ & 11.0 & 10.1 & 10.1 & 10.1 & 11.8 & 13.2 & 11.8 & 12.0 & 11.3 & 11.1 & 22.5 & 268 & 103 \\
\hline $\mathbf{P}$ & 0 & 0 & 2.4 & 0 & 2.4 & 0 & 2.4 & 0 & 0.7 & 0 & 1.6 & 19 & 7 \\
\hline \multicolumn{14}{|c|}{ Clover + inorganic } \\
\hline $\mathbf{N}$ & 11.0 & 10.1 & $\mathbf{0}$ & 10.1 & 0 & 13.2 & $\mathbf{0}$ & 12.0 & $\mathbf{0}$ & 11.1 & 13.5 & 161 & 62 \\
\hline $\mathbf{P}$ & $\mathbf{0}$ & $\mathbf{0}$ & 3.3 & $\mathbf{0}$ & 4.9 & $\mathbf{0}$ & 2.4 & $\mathbf{0}$ & 0.7 & $\mathbf{0}$ & 2.3 & 27 & 10 \\
\hline \multicolumn{14}{|c|}{ Broiler litter } \\
\hline Dry mass & 228 & 294 & 273 & 378 & 272 & 247 & 249 & 254 & 240 & 264 & 539 & 6421 & 2463 \\
\hline $\mathbf{N}$ & 9.6 & 9.9 & 8.5 & 13.1 & 10.1 & 6.4 & 12.4 & 9.9 & 7.9 & 9.3 & 19.4 & 231 & 89 \\
\hline $\mathbf{P}$ & 4.3 & 7.6 & 6.2 & 7.9 & 5.9 & 5.3 & 3.6 & 3.3 & 7.6 & 10.2 & 12.4 & 147 & 56 \\
\hline
\end{tabular}

$\dagger$ Equivalent concentration of nutrient added, assuming $84 \mathrm{~kg} \mathrm{~m}^{-2}$ soil in $6 \mathrm{~cm}$ depth.

+ Equivalent concentration of nutrient added, assuming $219 \mathrm{~kg} \mathrm{~m}^{-2}$ soil in $15 \mathrm{~cm}$ depth.

tion strategy. In addition, we wanted to ascertain the impact of forage harvest strategy (i.e., grazed and ungrazed management systems) on total and Mehlich-I extractable soil $\mathrm{P}$ during the first five years of grass management following conversion from long-term cultivated cropland.

\section{MATERIALS AND METHODS}

\section{Site Characteristics}

A 15 -ha upland field $\left(33^{\circ} 22^{\prime} \mathrm{N}, 83^{\circ} 24^{\prime} \mathrm{W}\right)$ in the Greenbrier Creek subwatershed of the Oconee River watershed near Farmington, GA, had previously been conventionally cultivated with wheat (Triticum aestivum L.), soybean [Glycine $\max ($ L.) Merr.], and cotton (Gossypium hirsutum L.) for several decades prior to sprigging of 'Coastal' bermudagrass in 1991. Mean annual temperature of the area is $16.5^{\circ} \mathrm{C}$, rainfall is $1250 \mathrm{~mm}$, potential evaporation is $1560 \mathrm{~mm}$, and elevation is 205 to $215 \mathrm{~m}$ above sea level. Sampled on a 30-m grid, the frequency of soil series was $46 \%$ Madison, $22 \%$ Cecil, $13 \%$ Pacolet, 5\% Appling, 2\% Wedowee (fine, kaolinitic, thermic Typic Kanhapludults); $11 \%$ Grover (fine-loamy, micaceous, thermic Typic Hapludults); and 1\% Louisa (loamy, micaceous, thermic, shallow Ruptic-Ultic Dystrudepts). Soil textural frequency of the Ap horizon was $75 \%$ sandy loam, $12 \%$ sandy clay loam, $8 \%$ loamy sand, and $4 \%$ loam. Depth of the Ap horizon was $21 \pm 12 \mathrm{~cm}$.

\section{Experimental Design}

The experimental design was a split-paddock with three replications. Individual paddocks were $0.69 \pm 0.03$ ha. Spatial design of paddocks minimized runoff contamination and handling of animals through a central roadway. Each paddock contained a $3 \times 4 \mathrm{~m}$ shade, mineral feeder, and water trough placed in a line $15-\mathrm{m}$ long near the top of the landscape. Unharvested and hayed exclosures within a paddock were 0.01 ha each and placed to minimize runoff from the grazed paddock. Whole paddocks were fertilization strategy $(n=3)$ and split-paddocks were harvest strategy $(n=4)$ for a total of 36 experimental units.

Fertilization strategy was based on application of $\approx 200 \mathrm{~kg}$ $\mathrm{N} \mathrm{ha}{ }^{-1} \mathrm{yr}^{-1}$ from (i) inorganic-only as $\mathrm{NH}_{4} \mathrm{NO}_{3}$ broadcast in split applications in May and July, (ii) crimson clover cover crop plus supplemental inorganic fertilizer with half assumed fixed by clover biomass and the other half as $\mathrm{NH}_{4} \mathrm{NO}_{3}$ broad- cast in July, or (iii) broiler litter broadcast in split applications in May and July. Details of fertilizer applications each year are reported in Table 1. Phosphorus application varied among treatments; triple superphosphate $\left(46 \% \mathrm{P}_{2} \mathrm{O}_{5}\right)$ was applied to inorganic-only and clover plus inorganic treatments based on soil testing recommendations for bermudagrass and clover. Broiler litter met $\mathrm{N}$ requirements, but supplied excess $\mathrm{P}$. Crimson clover was direct-drilled in the clover treatment at $10 \mathrm{~kg}$ $\mathrm{ha}^{-1}$ in October each year. All paddocks were mowed in late April following soil sampling, and residue was allowed to decompose [i.e., clover biomass in clover plus inorganic treatment, and winter annual weeds, primarily Lolium multiflorum Lam. (syn. L. italicum A. Braun.) and Bromus catharticus Vahl., in other treatments].

Harvest strategy mimicked a gradient in forage utilization consisting of (i) unharvested (biomass cut and left in place at the end of growing season), (ii) low grazing pressure (putand-take system to maintain $\approx 4 \mathrm{Mg} \mathrm{ha}^{-1}$ of available forage), (iii) high grazing pressure (put-and-take system to maintain $\approx 2 \mathrm{Mg} \mathrm{ha}^{-1}$ of available forage), and (iv) hayed monthly in summer at 4-cm height to remove aboveground biomass. Yearling Angus steers grazed paddocks during a 140-d period from mid May until early October each year, except during the first year of treatment implementation (1994) when grazing began in July due to repairs to infrastructure following a tornado. No grazing occurred in the winter. Animals were weighed, available forage determined, and paddocks restocked on a monthly basis. Based on animal gain and mean consumption of mineral supplement, grazed treatments received an additional 1 to $1.3 \mathrm{~g} \mathrm{P} \mathrm{m}^{-2} \mathrm{yr}^{-1}$, depending upon grazing pressure.

\section{Soil Sampling}

Two different soil sampling protocols were employed. Sampling Protocol I was used to characterize soil properties in the surface $6 \mathrm{~cm}$ in 2- or 3-cm-depth increments. Sampling Protocol II characterized soil properties within the surface $15 \mathrm{~cm}$. These two soil sampling protocols were employed to be able to distinguish changes in nutrient content nearest the surface where applications were made, as well as detect changes in the traditional zone of sampling (e.g., $0-15 \mathrm{~cm}$ ).

In Sampling Protocol I, soil was sampled in April prior to grazing during most years. Hayed and unharvested exclosures were sampled in July, rather than April during 1994. Sampling locations within grazed paddocks were within a 3-m radius of fixed points on a $30-\mathrm{m}$ grid. Due to the nonuniform dimensions of paddocks, sampling frequencies within a paddock varied 
from four to nine, averaging $7 \pm 1$. Two sampling locations were fixed within each hayed and unharvested exclosure. At each soil sampling location, surface residue including plant stubble was cut to the mineral surface and collected from a $0.25-\mathrm{m}^{2}$ area following removal of vegetation at a height of 4 $\mathrm{cm}$ with battery-powered hand shears prior to soil sampling. During 1994 and 1995, soil was sampled at depths of 0 to 2, 2 to 4 , and 4 to $6 \mathrm{~cm}$ from the composite of two 8.5 -cm-diam. cores within each sampling location. During 1996 to 1998, soil was sampled to the same depths from the composite of nine 4.1-cm-diam cores within each sampling location. Soil was airdried and ground to $<2 \mathrm{~mm}$ in a mechanical grinder in 1994 and 1995 . Soil was oven-dried $\left(55^{\circ} \mathrm{C}, 72 \mathrm{hr}\right)$ and gently crushed to pass a $4.75-\mathrm{mm}$ screen in other years. Beginning in 1999, the sampling strategy was revised to (i) more directly address the zonal changes in pastures in response to animal behavior near shade and water sources, (ii) collect soil to deeper depths, and (iii) collect soil earlier in the spring to facilitate sampling under wetter conditions. Soil (4.1-cm-diam. core) was collected following removal of surface residue from a composite of eight randomly selected $0.04-\mathrm{m}^{2}$ areas within each of three zones within paddocks (i.e., 0- to 30-, 30- to 70-, and 70to 120 -m distances from livestock shades) and within each exclosure at depths of 0 to 3,3 to 6,6 to 12 , and 12 to $20 \mathrm{~cm}$, and treated as described previously.

In Sampling Protocol II, soil was sampled with a 4.1-cmdiam core collected in winter months. From 1994 to 1998 , sampling locations within paddocks were the same as those described for Sampling Protocol I, but at depths of 0 to 6 and 6 to $15 \mathrm{~cm}$. Subsamples within experimental units (i.e., 36 paddocks and exclosures) were composited prior to laboratory analyses by mixing equal portions from each. In 1999, subsamples represented three cores (4.1-cm diam) at 5-, 30-, and $70 \mathrm{~m}$ distances from shades within grazed paddocks and two cores in exclosures collected at a single depth of 0 to $15 \mathrm{~cm}$. Subsamples were composited prior to laboratory analyses in 1999.

\section{Laboratory Analyses}

Soil bulk density was calculated from the oven-dried soil weight and coring device volume for samples collected using Sampling Protocol I. Bulk density was not determined in Sampling Protocol II, but based on the results of Sampling Protocol I, assumed to be $1.4 \mathrm{Mg} \mathrm{m}^{-3}$ at a depth of 0 to $6 \mathrm{~cm}$, and $1.5 \mathrm{Mg} \mathrm{m}^{-3}$ at a depth of 6 to $15 \mathrm{~cm}$ for calculation of soil properties at a depth of 0 to $15 \mathrm{~cm}$. Soil bulk density from Sampling Protocol I was reported in Franzluebbers et al. (2001) and used to calculate Mehlich-I extractable soil P on a volumetric basis.

Mehlich-I extractable soil P (Nelson et al., 1953) was determined $(10 \mathrm{~g}$ soil shaken with $40 \mathrm{~mL}$ of $0.05 \mathrm{M} \mathrm{HCl}+0.0125 \mathrm{M}$ $\mathrm{H}_{2} \mathrm{SO}_{4}$ for $15 \mathrm{~min}$ and filtered) with a molybdate autoanalyzer technique (Olsen and Sommers, 1982). Total soil P of the 0to 3- and 3- to 6-cm depths was determined with inductively coupled plasma spectroscopy (ICPS) following perchloric acid digestion (Olsen and Sommers, 1982) for soils collected in February 1999, for which three subsampling units (i.e., $20 \mathrm{~g}$ from each of the samples representing the 0 to 30,30 to 70 , and 70 to $120 \mathrm{~m}$ distances from shade) within each grazed paddock were composited. The University of Georgia Agricultural and Environmental Services Laboratory conducted ICPS analyses. Although perchloric acid digestion may not yield $100 \%$ total $\mathrm{P}$, the analysis of results should still be a good indication of changes in less labile forms of $\mathrm{P}$ due to pasture management strategies.

\section{Statistical Analyses}

Data from subsamples within an experimental unit were averaged and not considered as a source of variation in the analysis of variance, except when analyzing lateral redistribution within paddocks in 1999 (SAS Institute, 1990). Within-depth, acrossdepth, within-year, and across-year analyses were conducted according to the split-plot design with three replications. Acrossdepth analyses considered the bulk density of soil in calculating standing stock values of total and available nutrients. Linear regression analyses were performed on mean values from three replications of each treatment within a year to estimate changes with time. Effects were considered significant at $P \leq 0.1$.

\section{RESULTS AND DISCUSSION Soil P Depth Distribution}

Mehlich-I extractable soil $\mathrm{P}$ at the beginning of the study in April 1994 from Sampling Protocol I decreased with soil depth, averaging $60 \pm 47 \mathrm{mg} \mathrm{kg}^{-1}$ at a depth of 0 to $2 \mathrm{~cm}, 44 \pm 21 \mathrm{mg} \mathrm{kg}^{-1}$ at a depth of 2 to $4 \mathrm{~cm}$, and $32 \pm 20 \mathrm{mg} \mathrm{kg}^{-1}$ at a depth of 4 to $6 \mathrm{~cm}$ across all treatments (Fig. 1). From Sampling Protocol II in November 1994, Mehlich-I extractable soil P averaged $29 \pm 15 \mathrm{mg} \mathrm{kg}^{-1}$ at a depth of 0 to $6 \mathrm{~cm}$, and $13 \pm$ $10 \mathrm{mg} \mathrm{kg}^{-1}$ at a depth of 6 to $15 \mathrm{~cm}$ across all treatments (Table 2). The equivalent concentration of Mehlich-I extractable soil $\mathrm{P}$ in $15 \mathrm{~cm}$ was $19 \mathrm{mg} \mathrm{kg}^{-1}$, which is rated as a medium soil test level by the University of Georgia Cooperative Extension Service. Mehlich-I extractable soil $\mathrm{P}$ was higher at all sampling depths in the unharvested with broiler litter treatment compared with all other treatments at the initiation of the experiment (Fig. 1, Table 2). Two of the three replications of this treatment were allocated to hot spots in the field, which may have been caused by previous land management activities that we were unaware of prior to experimentation (e.g., historical locations of small feedlots, farmstead, septic system, etc., with concentration of organic nutrients).

With time, the surface $2 \mathrm{~cm}$ of soil became enriched in Mehlich-I extractable soil P in all management systems (Fig. 1). Surface enrichment was likely due to application of either inorganic or organic amendments (Table 1), deposition of feces, and decomposition of ungrazed plant residues at the soil surface. Mehlich-I extractable soil $\mathrm{P}$ was rarely significantly different between inorganic-only and clover plus inorganic amendments at any depths. Averaged across these two fertilization strategies and across harvest management strategies, Mehlich-I extractable soil $\mathrm{P}$ at a depth of 0 to $2 \mathrm{~cm}$ increased $11 \mathrm{mg} \mathrm{kg}^{-1}$ $\mathrm{yr}^{-1}$ during the first $4 \mathrm{yr}$, compared with insignificant changes in Mehlich-I extractable soil $\mathrm{P}$ of 2 and $1 \mathrm{mg} \mathrm{kg}^{-1}$ $\mathrm{yr}^{-1}$ at depths of 2 to 4 and 4 to $6 \mathrm{~cm}$, respectively. However, changes in Mehlich-I extractable soil P with broiler litter application were more dramatic because of greater $\mathrm{P}$ addition, increasing at rates of 15,6 , and $5 \mathrm{mg} \mathrm{kg}^{-1} \mathrm{yr}^{-1}$ at depths of 0 to 2,2 to 4 , and 4 to $6 \mathrm{~cm}$, respectively, during the first 4 yr. Lack of physical soil disturbance with surface application of amendments limited downward movement of $\mathrm{P}$ into the soil. Even with the five to eight times higher rate of $\mathrm{P}$ application 


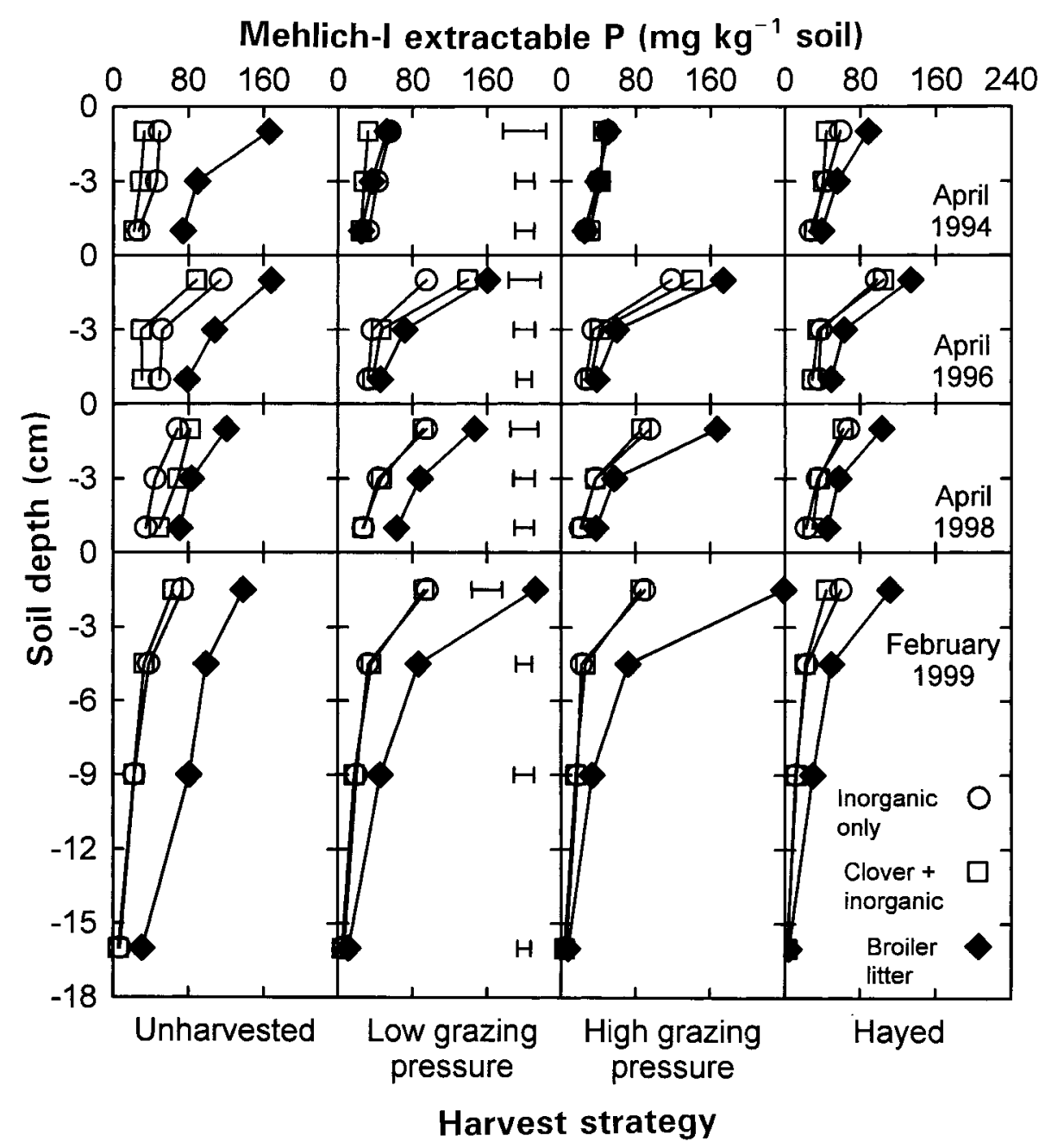

Fig. 1. Depth distribution of Mehlich-I extractable soil phosphorus using Sampling Protocol I as affected by fertilization and harvest strategies during the first $5 \mathrm{yr}$ of bermudagrass management. Horizontal bars are LSD at $\boldsymbol{P}=0.1$ to separate all combinations of fertilization and harvest strategies within a soil depth.

with broiler litter compared with other fertilization strategies, significant changes in Mehlich-I extractable soil $\mathrm{P}$ were limited to within the surface $12 \mathrm{~cm}$ of soil at the end of $5 \mathrm{yr}$ (Fig. 1).

\section{Fertilization Strategy Impacts on Soil P}

Using Sampling Protocol I to calculate the mean Mehlich-I extractable soil $\mathrm{P}$ at a depth of 0 to $6 \mathrm{~cm}$ revealed significant changes with time that were dependent upon both fertilization and harvest strategies (Fig. 2). The change in Mehlich-I extractable soil $\mathrm{P}$ was not significantly different between inorganic-only and clover plus inorganic amendments under any of the harvest strategies $\left(1.6 \pm 2.4 \mathrm{mg} \mathrm{kg}^{-1} \mathrm{yr}^{-1}\right.$, mean $\pm \mathrm{SD}$ among treatments). However, broiler litter application [which supplied 5-8 times more $\mathrm{P}$ than other fertilization strategies (Table 1)] resulted in a significantly greater rate of accumulation in Mehlich-I extractable soil P under low and high grazing pressures $\left(17 \mathrm{mg} \mathrm{kg}^{-1} \mathrm{yr}^{-1}\right)$ compared with other fertilization strategies. Under unharvested and hayed strategies, broiler litter application did not signifi- cantly alter Mehlich-I extractable soil $\mathrm{P}$ with time. Under unharvested management, Mehlich-I extractable soil $\mathrm{P}$ was initially high and did not change with time, which may have been due to large random variability with initially high levels of $\mathrm{P}$ and sequestration of a significant quantity of $\mathrm{P}$ in surface residue [surface residue $\mathrm{P}$ was not measured, but surface residue $\mathrm{C}$ averaged $377 \mathrm{~g} \mathrm{~m}^{-2}$ when unharvested and $83 \mathrm{~g} \mathrm{~m}^{-2}$ when hayed (Franzluebbers et al., 2001)]. Haying of bermudagrass would have removed $\mathrm{P}$ derived from the soil in harvested biomass (i.e., estimated at $2.0 \mathrm{~g} \mathrm{P} \mathrm{m}^{-2} \mathrm{yr}^{-1}$ based on mean dry matter harvest of $732 \mathrm{~g} \mathrm{~m}^{-2} \mathrm{yr}^{-1}$ ) and could have limited accumulation of Mehlich-I extractable soil P. Grazing of bermudagrass results in ingestion of forage containing $\mathrm{P}$ taken up from the soil, but the return of feces to the soil surface allows most of the $\mathrm{P}$ to cycle within the paddock. We estimate animal gain to have removed 0.3 to $0.5 \mathrm{~g} \mathrm{P} \mathrm{m}^{-2} \mathrm{yr}^{-1}$, depending upon grazing pressure.

From Sampling Protocol II, Mehlich-I extractable soil $P$ at a depth of 0 to $6 \mathrm{~cm}$ in November 1994 was significantly lower under clover plus inorganic than under 
Table 2. Mehlich-I extractable $P$ concentration ( $\mathrm{mg} \mathrm{kg}^{-1}$ soil) using Sampling Protocol II as affected by fertilization strategy (inorganic, clover + inorganic, and broiler litter) and harvest strategy [unharvested (UH), low grazing pressure (LG), high grazing pressure (HG), and hayed (H)] during the first 5 yr of forage management.

\begin{tabular}{|c|c|c|c|c|c|c|c|c|c|c|c|c|c|c|c|c|c|}
\hline \multirow[b]{2}{*}{ Soil depth } & \multicolumn{5}{|c|}{ Inorganic } & \multicolumn{5}{|c|}{ Clover + inorganic } & \multicolumn{5}{|c|}{ Broiler litter } & \multicolumn{2}{|c|}{$\mathbf{L S D}_{(P=0.1)}$} \\
\hline & UH & $\mathbf{L G}$ & HG & $\mathbf{H}$ & Mean & UH & $\mathbf{L G}$ & HG & $\mathbf{H}$ & Mean & UH & $\mathbf{L G}$ & HG & $\mathbf{H}$ & Mean & All & Means \\
\hline \multicolumn{18}{|l|}{ cm } \\
\hline \multicolumn{18}{|c|}{ November 1994 (at the end of 1 yr of management) } \\
\hline 0 to 6 & 37 & 24 & 19 & 26 & 26 & 17 & 14 & 19 & 23 & 18 & 56 & 36 & 27 & 46 & 41 & 11 & 5 \\
\hline 6 to 15 & 20 & 13 & 7 & 11 & 13 & 11 & 7 & 7 & 16 & 10 & 28 & 12 & 7 & 14 & 15 & 11 & 5 \\
\hline 0 to 15 & 26 & 17 & 11 & 16 & 18 & 13 & 10 & 12 & 18 & 13 & 39 & 21 & 14 & 26 & 25 & 9 & 4 \\
\hline \multicolumn{18}{|c|}{ February 1996 (at the end of 2 yr of management) } \\
\hline 0 to 6 & 35 & 22 & 24 & 23 & 26 & 25 & 21 & 20 & 16 & 20 & 56 & 53 & 44 & 38 & 47 & 14 & 7 \\
\hline 6 to 15 & 11 & 9 & 6 & 7 & 8 & 10 & 8 & 6 & 8 & 8 & 21 & 14 & 9 & 11 & 14 & 8 & 4 \\
\hline 0 to 15 & 20 & 14 & 13 & 13 & 15 & 16 & 13 & 11 & 11 & 13 & 34 & 29 & 22 & 21 & 27 & 9 & 5 \\
\hline \multicolumn{18}{|c|}{ October 1996 (at the end of 3 yr of management) } \\
\hline 0 to 6 & 34 & 26 & 27 & 26 & 28 & 24 & 30 & 30 & 30 & 29 & 69 & 58 & 47 & 30 & 51 & 12 & 6 \\
\hline 6 to 15 & 11 & 9 & 7 & 12 & 10 & 10 & 8 & 8 & 8 & 9 & 30 & 19 & 11 & 9 & 18 & 11 & 5 \\
\hline 0 to 15 & 20 & 15 & 14 & 17 & 17 & 15 & 16 & 17 & 16 & 16 & 45 & 34 & 25 & 17 & 30 & 9 & 4 \\
\hline \multicolumn{18}{|c|}{ October 1997 (at the end of $4 \mathrm{yr}$ of management) } \\
\hline 0 to 6 & 33 & 33 & 28 & 28 & 31 & 36 & 40 & 34 & 35 & 36 & 85 & 65 & 59 & 53 & 65 & 17 & 8 \\
\hline 6 to 15 & 11 & 10 & 9 & 8 & 10 & 11 & 14 & 11 & 13 & 12 & 57 & 21 & 11 & 17 & 26 & 24 & 12 \\
\hline 0 to 15 & 20 & 19 & 17 & 16 & 18 & 20 & 24 & 20 & 21 & 21 & 68 & 38 & 29 & 31 & 41 & 20 & 10 \\
\hline \multicolumn{18}{|c|}{ February 1999 (at the end of 5 yr of management) } \\
\hline 0 to 15 & 26 & 30 & 21 & 15 & 23 & 16 & 23 & 25 & 16 & 20 & 65 & 51 & 58 & 27 & 50 & 17 & 8 \\
\hline \multicolumn{18}{|c|}{$\underline{\text { Linear rate of change }\left(\mathrm{mg} \mathrm{kg}^{-1} \mathrm{yr}^{-1}\right)}$} \\
\hline 0 to $6_{(1-4 \text { yr })}$ & -1.3 & 3.1 & 3.0 & 0.9 & 1.4 & 5.6 & 8.7 & 5.5 & 5.0 & 6.2 & 10.0 & 9.2 & 9.9 & 1.3 & 7.6 & 8.2 & 4.1 \\
\hline 6 to $\left.15_{(1-4} \mathrm{yr}\right)$ & -2.7 & -0.9 & 0.7 & -0.4 & -0.8 & 0.0 & 2.1 & 1.4 & -0.9 & 0.7 & 9.6 & 3.2 & 1.4 & 0.7 & 3.7 & 4.9 & 2.4 \\
\hline 0 to $15_{(1-5 \mathrm{yr})}$ & -0.2 & 3.0 & 2.2 & $-\mathbf{0 . 1}$ & 0.0 & 1.0 & 3.8 & 3.5 & 0.5 & 2.8 & 8.6 & 6.9 & 9.4 & 1.1 & 5.2 & 5.6 & 2.8 \\
\hline
\end{tabular}

inorganic-only fertilization when averaged across harvest strategies, but became similar during remaining years due to higher inorganic P fertilization to support adequate clover growth (Table 2). Similar to the results using Sampling Protocol I, Mehlich-I extractable soil P increased with time under broiler litter fertilization at a depth of 0 to $6 \mathrm{~cm}\left(7.6 \mathrm{mg} \mathrm{kg}^{-1} \mathrm{yr}^{-1}\right)$, as well as at a depth of 6 to $15 \mathrm{~cm}\left(3.7 \mathrm{mg} \mathrm{kg}^{-1} \mathrm{yr}^{-1}\right)$, when averaged across harvest strategies.

At a depth of 0 to $6 \mathrm{~cm}$, the rate of accumulation in Mehlich-I extractable soil $\mathrm{P}$ averaged across harvest strategies during the first $4 \mathrm{yr}$ of management was $1.4 \mathrm{mg}$ $\mathrm{kg}^{-1} \mathrm{yr}^{-1}$ with inorganic-only fertilization (which supplied an equivalent of $19 \mathrm{mg} \mathrm{kg}^{-1} \mathrm{yr}^{-1}$ of total P), $6.2 \mathrm{mg}$ $\mathrm{kg}^{-1} \mathrm{yr}^{-1}$ with clover plus inorganic fertilization (which supplied an equivalent of $27 \mathrm{mg} \mathrm{kg}^{-1} \mathrm{yr}^{-1}$ of total $\mathrm{P}$ ), and $7.6 \mathrm{mg} \mathrm{kg} \mathrm{yr}^{-1}$ with broiler litter fertilization (which supplied an equivalent of $147 \mathrm{mg} \mathrm{kg}^{-1} \mathrm{yr}^{-1}$ of total P) (Tables 1 and 2). Accumulation of Mehlich-I extractable soil $\mathrm{P}$ as a percentage of total surface-applied $\mathrm{P}$ in our study (i.e., 5 to $23 \%$ ) was lower than the accumulation percentage of $51 \pm 12 \%$ with incorporation of broiler litter in 10 soils from Oklahoma incubated for $7 \mathrm{~d}$ (Sharpley, 1995). Long-term surface application of $\mathrm{P}$ may lead to chemical and biological transformations in the organic-rich surface residue and immediate surface soil that reduces overall $\mathrm{P}$ extractability due to organicinorganic cycling. From a survey of 12 paired pastures in northern Alabama, the increase in Mehlich-I extractable soil $\mathrm{P}$ at a depth of 0 to $15 \mathrm{~cm}$ at the end of $21 \pm$ $4 \mathrm{yr}$ represented $12 \%$ of total $\mathrm{P}$ applied in broiler litter (Kingery et al., 1994). From a 3-yr study in Nova Scotia, the percentage of $\mathrm{P}$ applied in composted and fresh poultry manure that contributed to an increase in ex- tractable soil $\mathrm{P}$ at a depth of 0 to $15 \mathrm{~cm}$ was $29 \pm 8 \%$ and $17 \pm 10 \%$, respectively (Warman and Cooper, 2000).

At a depth of 0 to $15 \mathrm{~cm}$, Mehlich-I extractable soil P averaged across harvest strategies increased during the first $5 \mathrm{yr}$ under broiler litter $\left(5.2 \mathrm{mg} \mathrm{kg}^{-1} \mathrm{yr}^{-1}\right)$ and under clover plus inorganic fertilization $\left(2.8 \mathrm{mg} \mathrm{kg}^{-1}\right.$ $\mathrm{yr}^{-1}$ ), but remained unchanged under inorganic-only fertilization (Table 2). Based on the quantity of P supplied to the soil through fertilization (Table 1), the proportion that contributed to an increase in the Mehlich-I

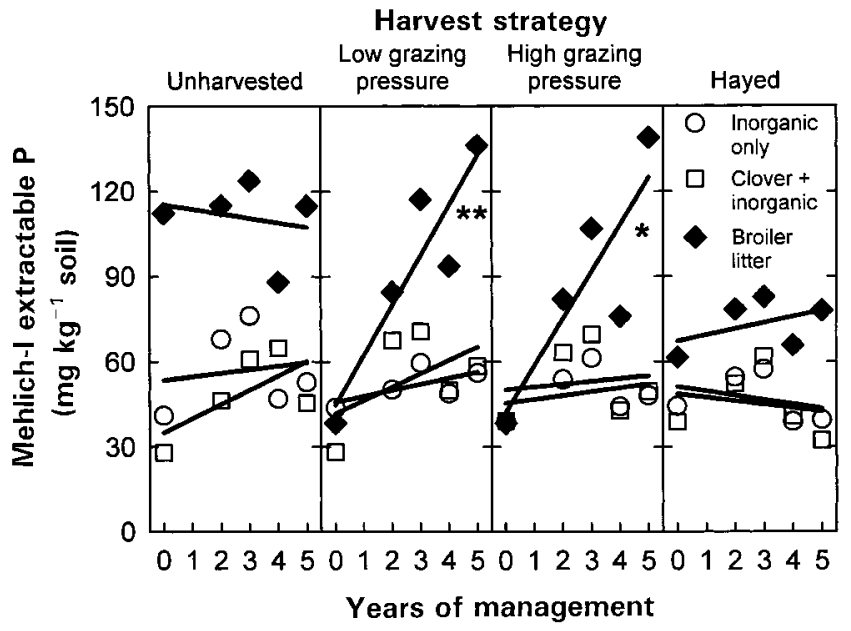

Fig. 2. Temporal change in Mehlich-I extractable soil phosphorus using Sampling Protocol I at a depth of 0 to $6 \mathrm{~cm}$ as affected by fertilization and harvest strategies during the first $5 \mathrm{yr}$ of bermudagrass management. Within a harvest strategy, regression lines marked with $*$ and $* *$ are significantly different from other fertilization strategies at $P<0.05$ and $P<0.01$, respectively. 
extractable soil $\mathrm{P}$ pool at a depth of 0 to $15 \mathrm{~cm}$ was $0 \%$ with inorganic-only fertilization, $28 \%$ with clover plus inorganic fertilization, and $9 \%$ with broiler litter fertilization. Assuming $\mathrm{P}$ was not lost from the 0 to $15 \mathrm{~cm}$ depth of soil, then P from broiler litter was either initially in a less available form or became quickly transformed into less available forms (i.e., a part of the nonextractable $\mathrm{P}$ pool). Loss of $\mathrm{P}$ could have occurred through surface runoff of soluble and, to a lesser extent, particulate-associated P (Sharpley, 1997). However, the quantity of $\mathrm{P}$ in surface runoff in our study was probably small, since application of $25 \mathrm{~g} \mathrm{~m}^{-2} \mathrm{yr}^{-1}$ of $\mathrm{P}$ (twice the application rate in our study) in poultry litter to tall fescue (Festuca arundinacea Schreb.) pastures at another Piedmont location in Georgia resulted in runoff losses of soluble P of only 0.9 to $1.2 \mathrm{~g} \mathrm{~m}^{-2} \mathrm{yr}^{-1}$ (Kuykendall et al., 1999).

At the end of $5 \mathrm{yr}$ of broiler litter application, Mehlich-I extractable soil $\mathrm{P}$ in the surface $15 \mathrm{~cm}$ (Table 2) was rated very high $\left(>37.5 \mathrm{mg} \mathrm{kg}^{-1}\right)$ under unharvested and low and high grazing pressures and high (20 to $37.5 \mathrm{mg} \mathrm{kg}^{-1}$ ) under haying for soils in the Piedmont region of Georgia (Plank, 1998). Bermudagrass grown on soils with ratings in the very high category would not be expected to respond to additional $\mathrm{P}$ fertilization. Several states have threshold values of soil-test P (dependent upon extraction method) ranging from 75 to $200 \mathrm{mg} \mathrm{kg}^{-1}$, above which environmental threats to water quality via surface runoff would be most likely (Sharpley et al., 1996). Fertilization with broiler litter was, therefore, effective at increasing Mehlich-I extractable soil $\mathrm{P}$ to agronomically productive levels in a relatively short period of time. Continued application of broiler litter could lead to excessive surface-soil $\mathrm{P}$ accumulation that could threaten water quality from runoff (Sharpley, 1995; Shreve et al., 1995; Pote et al., 1996).

Total soil $\mathrm{P}$ at depths of 0 to 3 and 3 to $6 \mathrm{~cm}$ under broiler litter fertilization was 30 to $55 \%$ greater than under inorganic-only and clover plus inorganic fertilization at the end of $5 \mathrm{yr}$ of management (Table 3). The greater application rate of $\mathrm{P}$ with broiler litter was easily distinguished as total soil P. Interestingly, total soil P under inorganic-only fertilization was significantly greater than under clover plus inorganic fertilization at depths of 3 to 6 and 0 to $6 \mathrm{~cm}$, despite no differences in MehlichI extractable soil $\mathrm{P}$ between these two fertilization strategies at the end of $5 \mathrm{yr}$. Total soil $\mathrm{P}$ was likely greater in plots randomly allocated to inorganic-only than clover plus inorganic fertilization prior to initiation of the experiment, since Mehlich-I extractable soil $\mathrm{P}$ was greater under inorganic-only than under clover plus inorganic fertilization in November 1994 (Table 2). At the end of $5 \mathrm{yr}$ of management, Mehlich-I extractable soil $\mathrm{P}$ at a depth of 0 to $3 \mathrm{~cm}$ as a percentage of total soil $\mathrm{P}$ was $16 \pm 3 \%$ with inorganic-only and clover plus inorganic fertilization and $25 \pm 4 \%$ with broiler litter fertilization. At a depth of 3 to $6 \mathrm{~cm}$, the percentages were generally lower (i.e., $8 \pm 2 \%$ with inorganic-only fertilization, $10 \pm 2 \%$ with clover plus inorganic fertilization, and $16 \pm 3 \%$ with broiler litter fertilization), reflecting increased residence time of applied $\mathrm{P}$ to soil and interaction with soil minerals that reduced availability. In the A horizon of soils in Quebec under different land uses, the percentage of total soil $\mathrm{P}$ as extractable soil $\mathrm{P}$ was 1 to $10 \%$ and generally decreased with soil depth (Beauchemin et al., 1996).

\section{Harvest Strategy Impacts on Soil $\mathbf{P}$}

Harvest strategy affected the rate of accumulation in Mehlich-I extractable soil P only with broiler litter fertilization at a depth of 0 to $6 \mathrm{~cm}$, which also became expressed in a significant effect to a depth of $15 \mathrm{~cm}$ (Table 2). Haying resulted in no significant change in Mehlich-I extractable soil $\mathrm{P}$ with time, but all other harvest strategies resulted in increases of 9 to $10 \mathrm{mg} \mathrm{kg}^{-1} \mathrm{yr}^{-1}$ at a depth of 0 to $6 \mathrm{~cm}$. Haying likely increased the demand for soil solution $\mathrm{P}$ by removing $\mathrm{P}$ in harvested biomass.

Averaged across fertilization strategies, total soil $\mathrm{P}$ at the end of $5 \mathrm{yr}$ of management at depths of 0 to 3 and 0 to $6 \mathrm{~cm}$ responded in a curvilinear manner to increasing level of forage utilization (Table 3 ). With no forage utilization (i.e., unharvested), total soil $\mathrm{P}$ at a depth of 0 to $6 \mathrm{~cm}$ averaged $427 \mathrm{mg} \mathrm{kg}^{-1}$, which was significantly less than under low grazing pressure $(467 \mathrm{mg}$ $\mathrm{kg}^{-1}$ ) and under high grazing pressure $\left(505 \mathrm{mg} \mathrm{kg}^{-1}\right)$. The highest forage utilization (i.e., haying), however, resulted in the lowest level of total soil P $\left(378 \mathrm{mg} \mathrm{kg}^{-1}\right)$. At a depth of 0 to $3 \mathrm{~cm}$, total soil $\mathrm{P}$ was greater (i) with inorganic-only fertilization under high than under low grazing pressure and haying, (ii) with clover plus inorganic fertilization under both grazing pressures compared with unharvested and haying strategies, and (iii) with broiler litter under high than under low grazing pressure, both of which were greater than under unharvested and haying strategies. Under both grazing pressures soil organic C content was greater at a depth of 0 to $6 \mathrm{~cm}$ than under unharvested and hayed strategies (Franzluebbers et al., 2001). A large portion of the total

Table 3. Total soil $\mathbf{P}$ digested in perchloric acid using Sampling Protocol I as affected by fertilization strategy (inorganic, clover + inorganic, and broiler litter) and harvest strategy [unharvested (UH), low grazing pressure (LG), high grazing pressure (HG), and hayed $(\mathrm{H})]$ at the end of $5 \mathrm{yr}$ of forage management.

\begin{tabular}{|c|c|c|c|c|c|c|c|c|c|c|c|c|c|c|c|c|c|}
\hline \multirow[b]{2}{*}{ Soil depth } & \multicolumn{5}{|c|}{ Inorganic } & \multicolumn{5}{|c|}{ Clover + inorganic } & \multicolumn{5}{|c|}{ Broiler litter } & \multicolumn{2}{|c|}{$\mathbf{L S D}_{(P=0.1)}$} \\
\hline & UH & LG & HG & $\mathbf{H}$ & Mean & UH & LG & HG & $\mathbf{H}$ & Mean & UH & LG & HG & $\mathbf{H}$ & Mean & All & Means \\
\hline cm & \multicolumn{17}{|c|}{$\mathrm{mg} \mathrm{kg}^{-1}$ soil } \\
\hline 0 to 3 & 496 & 448 & 580 & 427 & 488 & 348 & 572 & 480 & 351 & 438 & 568 & 699 & 919 & 535 & 680 & 108 & 54 \\
\hline 3 to 6 & 386 & 352 & 376 & 340 & 363 & 284 & 347 & 344 & 248 & 306 & 516 & 494 & 483 & 398 & 473 & 66 & 33 \\
\hline 0 to 6 & 432 & 387 & 456 & 378 & 413 & 311 & 439 & 399 & 295 & 361 & 537 & 575 & 660 & 460 & 558 & 65 & 33 \\
\hline
\end{tabular}


soil P may be organically bound (Sharpley et al., 1993), and therefore, accumulation of soil organic matter with cattle grazing compared with other harvest strategies may explain a part of these differences in total soil $\mathrm{P}$. Additionally, high grazing pressure may cycle more of the $\mathrm{P}$ taken up by plants into more resistant organic compounds found in feces, rather than as readily decomposable organic compounds in plant residues under low grazing pressure.

\section{Redistribution of Soil P within Grazed Paddocks}

Mehlich-I extractable soil $\mathrm{P}$ at the end of $5 \mathrm{yr}$ of management was not uniformly distributed within grazed paddocks (Fig. 3). With broiler litter fertilization, Mehlich-I extractable soil $\mathrm{P}$ was greatest within $30 \mathrm{~m}$ of animal shades compared with farther distances from shade at all soil depths. With clover plus inorganic fertilization, Mehlich-I extractable soil $\mathrm{P}$ was also greatest within $30 \mathrm{~m}$ of shades compared with farther distances, but significant only at depths of 0 to 3 and 3 to $6 \mathrm{~cm}$. With inorganic-only fertilization, Mehlich-I extractable soil P tended to be similar at 0 to 30 and 30 to $70 \mathrm{~m}$ distances from shades, but greater than at 70- to 120 -m distance at all soil depths. Cattle graze forage from throughout the paddock, but spend more time near shade, water, and mineral feeders where feces are more frequently deposited, and therefore, accumulation of nutrients can occur. Greater redistribution of Mehlich-I extractable soil $\mathrm{P}$ within paddocks with broiler litter fertilization may have occurred due to a greater supply of $\mathrm{P}$ available for forage uptake with subsequent deposition near shades. Redistribution of Mehlich-I extractable soil P in grazed paddocks with concentration near shade, water, and mineral feeder positions was also reported on similar soils in Georgia under tall fescue (Festuca arundinacea Schreb.) (Schomberg et al., 2000) and in Florida under bermudagrass (Mathews et al., 1994).

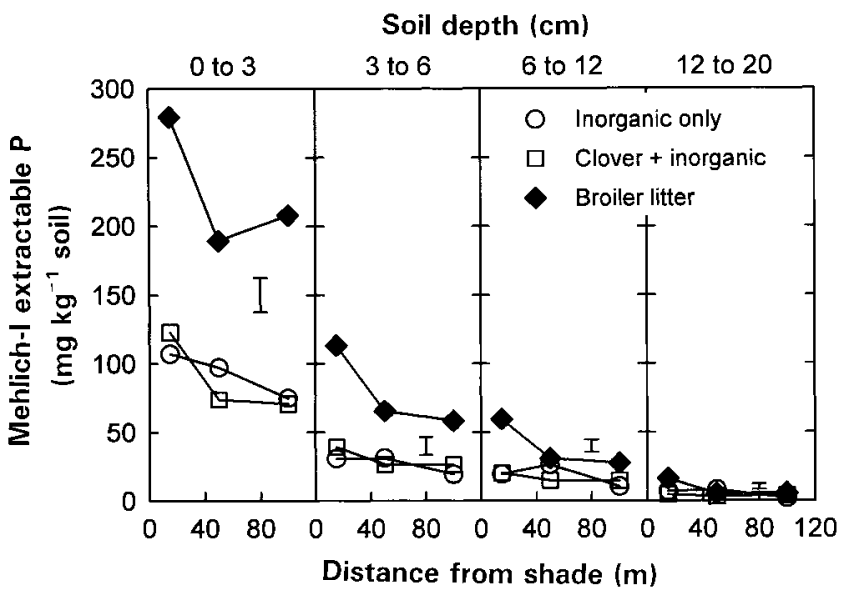

Fig. 3. Mehlich-I extractable soil phosphorus using Sampling Protocol I as affected by fertilization strategy averaged across low and high grazing pressures and as a function of distance from animal shades and soil depth. Error bar within a soil depth is LSD at $P=$ 0.1 to separate means among fertilization strategy and distance from shade.

\section{SUMMARY AND CONCLUSIONS}

Surface application of inorganic and organic sources of $\mathrm{P}$ led to relatively small increases in Mehlich-I extractable soil $\mathrm{P}$ with time (i.e., 5 to $23 \%$ of total $\mathrm{P}$ added was reflected as an increase in Mehlich-I extractable soil P). Changes in Mehlich-I extractable soil P during the first $5 \mathrm{yr}$ of grass management were limited primarily to the surface $2 \mathrm{~cm}$ of soil with relatively low application rates to maintain soil test $\mathrm{P}$ levels and extended down to a depth of $12 \mathrm{~cm}$ with a much higher application rate supplied by broiler litter to meet forage $\mathrm{N}$ demands. Lateral redistribution of nutrients due to cattle behavior resulted in Mehlich-I extractable soil P levels that were highest (i.e., $100 \%$ ) in the zone 0 to $30 \mathrm{~m}$ from animal shade/water, $76 \pm 29 \%$ at 30 to $70 \mathrm{~m}$, and $58 \pm 17 \%$ at 70 to $120 \mathrm{~m}$. Significant redistribution of Mehlich-I extractable soil $\mathrm{P}$ within grazed paddocks suggests that either (i) fertilization practices should be modified to avoid application near animal shades where nutrients accumulate due to preferential deposition of feces, or (ii) periodic relocation of animal shades and water supplies where practical to sites least susceptible to runoff. Under low and high cattle grazing pressures, Mehlich-I extractable soil $\mathrm{P}$ at a depth of 0 to $6 \mathrm{~cm}$ increased at a rate of $17 \mathrm{mg} \mathrm{kg}^{-1} \mathrm{yr}^{-1}$ with broiler litter application that supplied an equivalent of $147 \mathrm{mg}$ total $\mathrm{P} \mathrm{kg}^{-1} \mathrm{yr}^{-1}$. Haying of bermudagrass forage resulted in relatively constant Mehlich-I extractable soil P levels with time due to repeated harvest of nutrients in biomass. In contrast to haying, grazing and unharvested management strategies allowed $\mathrm{P}$ to cycle among soil, plant, and animal components resulting in significant increases in Mehlich-I extractable soil $\mathrm{P}$ with time, the extent of which depended upon total $\mathrm{P}$ input.

\section{ACKNOWLEDGMENTS}

We appreciate the technical expertise of A. David Lovell, Steven Knapp, Dwight Seman, Fred Hale, Ronald Phillips, Clara Parker, David Hildreth, and Evan Thomas.

\section{REFERENCES}

Anderson, S.J., K.E. Sanders, and K.J. Steyer. 1996. Effect of colloidal goethite and kaolinite on colorimetric phosphate analysis. J. Environ. Qual. 25:1332-1338.

Beauchemin, S., R.R. Simard, and D. Cluis. 1996. Phosphorus sorption-desorption kinetics of soil under contrasting land uses. J. Environ. Qual. 25:1317-1325.

Bruce, R.R., W.M. Snyder, A.W. White, Jr., A.W. Thomas, and G.W. Langdale. 1990. Soil variables and interactions affecting prediction of crop yield pattern. Soil Sci. Soc. Am. J. 54:494-501.

U.S. Dep. of Commerce. 1992. Census of Agriculture: Geographic area series 1B: U.S. summary and county level data. U.S. Dep. Commerce, Econ. and Statistics Admin., Bureau of the Census, Data User Services Div., Washington, DC.

Follett, R.F., and S.R. Wilkinson. 1995. Nutrient management in forages. In R.F. Barnes, D.A. Miller, and C.J. Nelson (ed.) Forages: Vol. II. Iowa State University Press, Ames, IA.

Franzluebbers, A.J., J.A. Stuedemann, and S.R. Wilkinson. 2001. Bermudagrass management in the Southern Piedmont USA. I. Soil and surface residue carbon and sulfur. Soil Sci. Soc. Am. J. 65:834-841.

Haynes, R.J., and P.H. Williams. 1993. Nutrient cycling and soil fertility in the grazed pasture ecosystem. Adv. Agron. 49:119-199. 
Kingery, W.L., C.W. Wood, D.P. Delaney, J.C. Williams, and G.L. Mullins. 1994. Impact of long-term land application of broiler litter on environmentally related soil properties. J. Environ. Qual. 23: $139-147$.

Kuykendall, H., M. Cabrera, C. Hoveland, M. McCann, and L. West. 1999. Grazing management effects on surface runoff from pastures fertilized with broiler litter. p. 260-263. In K.J. Hatcher (ed.) Proc. 1999 Georgia Water Resources Conf., Athens, GA. 30-31 Mar. 1999. Univ. of Georgia, Athens, GA.

Mathews, B.W., L.E. Sollenberger, and J.P. Tritschler, II. 1996. Grazing systems and spatial distribution of nutrients in pastures: Soil considerations. p. 213-229. In R.E. Joost and C.A. Roberts (ed.) Nutrient cycling in forage systems. Potash and Phosphate Institute and Foundation for Agronomic Research, Manhattan, KS.

Mathews, B.W., L.E. Sollenberger, V.D. Nair, and C.R. Staples. 1994. Impact of grazing management on soil nitrogen, phosphorus, potassium, and sulfur distribution. J. Environ. Qual. 23:1006-1013.

Nelson, W.L., A. Mehlich, and E. Winters. 1953. The development, evaluation, and use of soil tests for phosphorus availability. Agronomy 4:153-158.

Olsen, S.R., and L.E. Sommers. 1982. Phosphorus. p. 403-430. In A.L. Page, R.H. Miller, and D.R. Keeney (ed.) Methods of soil analysis. Part 2. Chemical and microbiological properties, 2nd ed. Agron. Monogr. 9. ASA and SSSA, Madison, WI.

Plank, C.O. 1998. Soil test handbook for Georgia. Univ. Georgia, Athens, GA.

Pote, D.H., T.C. Daniel, A.N. Sharpley, P.A. Moore, Jr., D.R. Ed- wards, and D.J. Nichols. 1996. Relating extractable soil phosphorus to phosphorus losses in runoff. Soil Sci. Soc. Am. J. 60:855-859.

SAS Institute. 1990. SAS user's guide: Statistics. 6th ed. SAS Inst., Cary, NC.

Schomberg, H.H., J.A. Stuedemann, A.J. Franzluebbers, and S.R Wilkinson. 2000. Spatial distribution of extractable phosphorus, potassium, and magnesium as influenced by fertilizer and tall fescue endophyte status. Agron. J. 92:981-986.

Sharpley, A.N. 1995. Dependence of runoff phosphorus on extractable soil phosphorus. J. Environ. Qual. 24:920-926.

Sharpley, A.N. 1997. Rainfall frequency and nitrogen and phosphorus runoff from soil amended with poultry litter. J. Environ. Qual. 26: $1127-1132$.

Sharpley, A.N., T.C. Daniel, J.T. Sims, and D.H. Pote. 1996. Determining environmentally sound soil phosphorus levels. J. Soil Water Conserv. 51:160-166.

Sharpley, A.N., S.J. Smith, and W.R. Bain. 1993. Nitrogen and phosphorus fate from long-term poultry litter applications to Oklahoma soils. Soil Sci. Soc. Am. J. 57:1131-1137.

Shreve, B.R., P.A. Moore, Jr., T.C. Daniel, D.R. Edwards, and D.M. Miller. 1995. Reduction of phosphorus in runoff from field-applied poultry litter using chemical amendments. J. Environ. Qual. 24: 106-111.

Warman, P.R., and J.M. Cooper. 2000. Fertilization of a mixed forage crop with fresh and composted chicken manure and NPK fertilizer: Effects on dry matter yield and soil and tissue N, P and K. Can. J. Soil Sci. 80:337-344. 